\title{
Influencing Factors of Social Media Marketing on Consumers Buying Decisions
}

\author{
Anjali Chaudhary \\ Assistant Professor, Business and Administration Department \\ College of Business Administration, Princess Nourahbint Abdulrahman University, \\ Riyadh, Kingdom of Saudi Arabia \\ E-Mail: anjali13481@gmail.com
}

\begin{abstract}
In recent years, the world has witnessed a kind of social communication between humans in virtual cyberspace. The social networking is popular in marketing which utilizes the platform to present various marketing programs and strategies. The studybased on the affecting influencing factors of social media marketing such as technology, infrastructure, culture, society inconsumers' buying decision in Saudi Arabia.The research focuses on consumer's behavior and responses, in terms of indirect advertising, exaggerating on praising the product or service, false advertising, deceitful, and unprofessional behaviors. The researchwas carried out the buying behavior of customer through survey questionnaire. The results of the study concluded there is a relationship between Social media marketing on consumer purchasing decisions. The result further showsthat e-advertising on the social media platforms has a negative impact on consumer purchasing behavior by stealth advertisement, unethical behavior, and fake advertise, and exaggeration on promoting a product to those who spend three hours or more on social networking sitesin the Kingdom of Saudi Arabia.

Keywords: Social Media, Marketing, Buying Decision
\end{abstract}

\section{INTRODUCTION}

The emergence of modern technology paved the road for development in all fields of cultural, social, economic and intellectual. Also, it opened new horizons in front of several concepts and perhaps the most prominent is Internet network. Now that it is known for high prevalence in all cities, and countries in which it links various parts to become one connected world. Also, it has become an important part of the lives of contemporary society. Furthermore, it made it possible to share, exchange ideas, experiences with each other, and thus became the best way to achieve its venue and communication between individuals and communities. Social networks, create sort of communication channel between sites and users on the one hand and between the users themselves, on the other hand. Due to the rapid spread of different social networks, many companies in different fields, have resorted to presence across these networks.

According to Global Web Index, social networking remains widely popular activity with $95 \%$ of internet users in Saudi adults say that they are a member of at least one platform (Global Web Index, 2016). Also, according to GWI reports that Face book remain the most popular platform in Saudi
Arabia with $85 \%$ of internet users as members (Global Web Index, 2016). Using this information on Face book or other social media sites businesses can obtain detailed information about their potential customers. Also, these platforms can identify each segment of consumers as what they like, dislikes then can be used as a target customer. As GWI charts shows YouTube enjoys the lead when it comes to visitors and users (Global Web Index, 2016). Moreover, Saudi Arabia is one of Snapchat best performing markets where $65 \%$ of internet users have an account (Global Web Index, 2016). Although in most markets we see snapchat usage peak substantially among teens, this is not the case in Saudi Arabia, where the internet population as a whole is just likely to be using it (Global Web Index, 2016). These indicate that Saudi Arabian social networks are more active than those in many other. Also, it indicates that there could be many advertisement agreements between these company or users and marketing department of businesses to attract targeted customers into buying or promoting products.

\section{OBJECTIVES OF THE STUDY}

The manifestation of social platforms that allows its users to be active, share and comment through its platform gave the crowd a chance to communicate. At the same time it is considered a great opportunity and hand in a silver plate to businesses to market itself.

1. To study influencing factors of Social media in consumers buying.

2. To highlight negative impacts of false marketing through social media at different platforms.

3. To study the false trading, frauds of social media.

\section{LITERATURE REVIEW}

Taylor (1965) claims "Market" and "trade" has a long history, yet marketing did not exist as a term until early 1900s. In the period of 1900-1910 the first marketing textbook was published and some institutional economics started to teach distribution which later lead to lunch advertisement and then promotion and pricing. Hunt (1976) adds that marketing got start in the sale department as it is every company has a sale group who want to be in the office of consumer. Carr, 1999 confirms that consumer research in a systematic way, because it is time consuming. 
Furthermore, they want someone else to find leads, which is in another word prospect. He wants them to distinguish between hot lead, worm lead, and cold. Bejou (1997) state marketing department was born from those people split from sales and became big enough to become its own department. As any new evolution, marketing had its share of criticisms; Goodwin, Nelson, Ackerman, \&Weisskopf (2008) criticize that marketing get consumer to want and spend more than they can afford. Besides, marketers are skilled at creating brand differentiation where it should not exist like with commodities.

Furthermore, based on Jaworski (1988), marketing has a profound impact on environmental costs, as marketers want to produce and sell more goods without considering the resources and environmental costs of purchasing goods. The planet earth is affected by the amount of production and the care with which is done. In the other hand Kotler (2008) suggests that environmental impact that is cost by marketing can be manageable by reinventing marketing strategy and implementing green marketing strategy and sustainability methodologies (Kotler, 2011). According to Sridevi(2014) celebrity advertisements gain popularity nowadays in social media platforms, that it has become one of the essential element in marketing industry. He believes that there is a great positive effect between customer buying intention and celebrity advertisements. Wave of customers then try to direct their attention to word of mouth products. Based on Prendergast, Ko, \& Siu Yin (2010) word of mouth became more reliable in social media advertisements specially Blogs. Their study results that tier is a direct relationship between the source of the platform, Blog in this study, and the products that are being promoted.

\section{RESEARCH METHODOLOGY}

The study included the theoretical presentation of previous studies that dealt with the subject of the study or one of its aspects. The field study has tested research hypotheses on the negative impact of marketing and online advertising on social networking sites on consumer behavior and the demographic factors expected to affect the variable through a field survey to allocate the purpose of measuring this variable. The study used Chi-square test for testing relationships between categorical variables.

\section{A. Collection of Data and Sample Size}

The sample size for the study considered were 235 after excluding 15 unsolicited questionnaires forms out of 250 that were distributed by e-mail using Google Forms. The validity of the measuring instrument was evaluated by finding the coefficient of loading the terms used in the questionnaire using Factor Analysis to measure Construct Analysis. The stability of the measuring instrument was evaluated in the internal consistency method, based on the extraction of the Cronbach's Alpha, by finding the correlation coefficient between the values of the terms used to measure each variable of the study.

\section{B. Statistical Analysis of the Study}

To achieve the objective of the study and to measure the impact of the electronic advertising on the consumer purchasing decision, the study followed the method of descriptive analysis, which depends on the study of the phenomenon as it exists in reality.

TABLE I DEMOGRAPHIC CHARACTERISTICS OF THE STUDY SAMPLE

\begin{tabular}{|c|c|c|c|}
\hline & Criteria & Frequency & Percentage \\
\hline \multirow{3}{*}{ Gender } & Female & 115 & $49 \%$ \\
\hline & Male & 120 & $51 \%$ \\
\hline & Total & 235 & $100 \%$ \\
\hline \multirow{6}{*}{ Age } & 12 to 19 & 29 & $12 \%$ \\
\hline & $20-25$ & 41 & $17 \%$ \\
\hline & $26-30$ & 66 & $28 \%$ \\
\hline & $31-35$ & 55 & $23 \%$ \\
\hline & 35 or older & 44 & $19 \%$ \\
\hline & Total & 235 & $100 \%$ \\
\hline \multirow{5}{*}{ Education } & School drop out & 1 & $0 \%$ \\
\hline & High school & 38 & $16 \%$ \\
\hline & $\begin{array}{l}\text { Bachelor } \\
\text { degree }\end{array}$ & 122 & $52 \%$ \\
\hline & $\begin{array}{l}\text { Higher } \\
\text { education }\end{array}$ & 74 & $32 \%$ \\
\hline & Total & 235 & $100 \%$ \\
\hline
\end{tabular}

Table I shows the characteristics of the sample (respondents), which included demographic (age, gender, and scientific qualification). It shows that the proportion of males reached 120 respondents out of 235 with (51\%). And the proportion of females is 115 out of 235 respondents with (49\%). We also note from the table that 66 out of 235 respondents who are $28 \%$ are between the ages of 26 and 33 years and are the highest, followed by age 31 - 35 with $23 \%$ with 55 respondents out of 235 of the population. While the age group of 12 - 19 ranks as the lowest proportion of 29 respondents out of 235 population with $12 \%$, topped by age group of 20-25 with 41 respondents out of 235 which represents $17 \%$. While the age group 35 years and above are 44 respondents out of 235 populations which reached $19 \%$.

TABLE II RESPONDENTS USE SOCIAL MEDIA IN A DAY ON AVERAGE

\begin{tabular}{|l|c|c|}
\hline \multicolumn{3}{|c|}{ Respondents use social media in a day on average } \\
\hline & Frequency & Percent \\
\hline 1 to 3 Hours & 75 & 31.9 \\
\hline 4 to 6 Hours & 81 & 34.5 \\
\hline Less than an 1 hours & 6 & 2.6 \\
\hline More than 6 hours & 73 & 31.1 \\
\hline Total & 235 & 100 \\
\hline
\end{tabular}

As shown in Table II and the majority of the sample is spending between 4-6 hours a day on average on social media platforms. Community of both male and female are 
uses social networking sites between 4-6 hours a day in average, 81 respondents out of 235 which represent $35 \%$. In fact, it is very close to those who use it more than 6 hours a day on average with 73 out of 235 on the population by $31 \%$ of the population. For the period of 1-3 hours in a day on average, 75 respondents out of 235 of the population with $31 \%$.

TABLE III RESPONDENTS WHO HAVE BEEN VICTIMIZED BY INFLUENCER PROMOTING A LOUSY PRODUCT

\begin{tabular}{|l|c|c|}
\hline \multicolumn{2}{|c|}{$\begin{array}{c}\text { Respondents who have been Victimized by influencer } \\
\text { promoting a lousy product }\end{array}$} \\
\hline & Frequency & Percent \\
\hline May be & 35 & 14.9 \\
\hline No & 94 & 40 \\
\hline Yes & 106 & 45.1 \\
\hline Total & 235 & 100 \\
\hline
\end{tabular}

From Table III, it is very clear that the proportion of people victimized by influencers or not are too close. 106 out of 235 of the respondents admit that they fall for a lousy product is higher in percentage with $45 \%$ compared with those who did not who are 94 out of 235 respondents by $40 \%$. Other 35 out of 235 respondents were not sure if they fall for a lousy product promoted by influencer are almost $15 \%$ of the population. Also, they emphasis that the frequency of customers victimized from an influencer by a lousy product is high with 106 respondents.

TABLE IV CONSUMER COMMON REACTION AFTER BUYING A LOUSY PRODUCT

\begin{tabular}{|l|c|c|c|c|}
\hline \multicolumn{4}{|c|}{ Consumer common reaction after buying a lousy product } \\
\hline & & & \\
& & & & \\
& & & & \\
\hline Anger! & 14 & 6.0 & 6.0 & 6.0 \\
\hline Filing a lawsuit against them & 5 & 2.1 & 2.1 & 8.1 \\
\hline $\begin{array}{l}\text { Losing trust of the product/ } \\
\text { company/ influencer }\end{array}$ & 66 & 28.1 & 28.1 & 36.2 \\
\hline Never been in the situation & 85 & 36.2 & 36.2 & 72.3 \\
\hline Nothing & 10 & 4.3 & 4.3 & 76.6 \\
\hline Other & 12 & 5.1 & 5.1 & 81.7 \\
\hline Start to bad mouth them & 43 & 18.3 & 18.3 & 100.0 \\
\hline Total & 235 & 100.0 & 100.0 & \\
\hline
\end{tabular}

Table IV shows that the majority of participants 85 out of 235 never been in a situation like so with a percentage of $36 \%$. However, respondents who were to be exposed to such experience lost trust are 66out of 235 which represent $28 \%$ of population. Bad mouth them came as second high negative reaction with 43 respondents out of 235 and $18 \%$ of the population. Extreme feel of anger represented by 14 respondents out of 235 of the population are $5 \%$. Thus, the negative reaction which is result from a bad experience is therefore higher than a positive experience with $59 \%$ to negative and $36 \%$ positive and $12 \%$ is other reaction.

TABLE V CONSUMER OPINION ABOUT ENFORCING LEGAL REGULATION ON SOCIAL MEDIA MARKETING

\begin{tabular}{|l|c|c|}
\hline \multicolumn{3}{|c|}{$\begin{array}{c}\text { Consumer opinion about enforcing legal regulation on } \\
\text { social media marketing }\end{array}$} \\
\hline & Frequency & Percent \\
\hline Agree & 43 & 18.3 \\
\hline Disagree & 2 & 0.9 \\
\hline Strongly agree & 169 & 71.9 \\
\hline Strongly Disagree & 1 & 0.4 \\
\hline To some extent & 20 & 8.5 \\
\hline Total & 235 & 100 \\
\hline
\end{tabular}

Table $\mathrm{V}$ indicates that the populations were asked on if they think that there should be lows and legal regulations concerning unethical activities on social media platforms, the vast majority strongly agrees with 169 out of 235 respondents with almost $72 \%$. Other 43 respondents out of 235 who represents $18 \%$ of the population agree, and 20 other respondents out of 235 which represents $8.5 \%$ think to some extent. In the other hand, only 2 respondents disagree and 1 strongly disagree which is equal to $1 \%$ between disagree and strongly disagree.

TABLE VI EFFECTS OF SOCIAL MEDIA

\begin{tabular}{|l|c|c|}
\hline \multicolumn{3}{|c|}{ Effects of social media } \\
\hline & Frequency & Percent \\
\hline Negatively & 41 & 17.4 \\
\hline Neither of & 56 & 23.8 \\
\hline Positively & 138 & 58.7 \\
\hline Total & 235 & 100 \\
\hline
\end{tabular}

Table VI shows the social media affected on consumers overall life, the majority answered positively: 138 out of 235 , with $58 \%$ of the population. The lowest proportion is to negative effect of social media on their overall life: 41 out of 23 , with $17 \%$ of the population. Neither of the above captured 56 respondents out of 235 , with $24 \%$ of the population. This indicates that there is a great impact of positive marketing through social media. Also, it indicates that there is slight negative impact of marketing through social media. Other population is not really sure if it was positive or negative impact of social media.

TABLE VII USUAL CONSUMPTION PERIOD OF SOCIAL MEDIA BY GENDER

\begin{tabular}{|l|c|c|c|}
\hline \multicolumn{2}{|c|}{ Usual consumption period in social media by gender } \\
\cline { 1 - 3 } & \multicolumn{2}{|c|}{ Gender } & \multirow{2}{*}{ Total } \\
\cline { 1 - 3 } & Female & Male & \\
\hline 1 to 3 Hours & 31 & 44 & 75 \\
\hline 4 to 6 Hours & 42 & 39 & 81 \\
\hline Less than an 1 hours & 4 & 2 & 6 \\
\hline More than 6 hours & 38 & 35 & 73 \\
\hline Total & 115 & 120 & 235 \\
\hline
\end{tabular}


As Table VII illustrates female consumption hours is more than male using social media platforms in a day on average. However, men are higher using social media platforms in the period 1-3 hours. Furthermore, the count of female and male for consumption of lower than an hour is very low with only (4) female, and (2) male. Thereby, the lowest count of period consumption scored is less than one hour in a day on average, female respondent came higher than men with female $1.7 \%$ and male $0.8 \%$. However, $13 \%$ of female uses social media in a period of 1 to 3 hours a day which is lower than male 44 respondents and $18.7 \%$.

TABLE VIII CONSUMER VICTIMIZED BY A LOUSY PRODUCT CATEGORIZED BY GENDER

\begin{tabular}{|l|c|c|c|}
\hline \multicolumn{3}{|c|}{$\begin{array}{c}\text { Consumer victimized by a lousy product categorized } \\
\text { by gender }\end{array}$} \\
\cline { 1 - 3 } & \multicolumn{2}{|c|}{ Gender } \\
\hline & Female & Male & \\
\hline 11 to 20 & 15 & 22 & 37 \\
\hline 6 to 10 & 31 & 25 & 56 \\
\hline Less than 5 & 39 & 38 & 77 \\
\hline More than 20 & 13 & 22 & 35 \\
\hline None & 17 & 13 & 30 \\
\hline Total & 115 & 120 & 235 \\
\hline
\end{tabular}

Table VIII expose how many influencers and public figures are in the respondents account by gender. Lowest count, which is none is higher in female, 17 respondents, in terms of gender with $7 \%$ of the population. Which means that $7 \%$ of female in the community do not follow any influencer, nor public figure account. Male,13 respondents, in the other hand are lower with $5.5 \%$ are not following any influencer nor public figure account.

Next, which is less than five account both male, 38 respondents and female, 39 respondents, are almost the same percentage of $16.5 \%$ female, and $16.1 \%$ male. For $6-$ 10 female, 31 respondents is higher with $13.1 \%$ compared with male, 25 respondents out of 235 with $10 \%$. From 1120 influencers, male with 22 respondents scored higher percentage with $9.3 \%$, and female, 15 respondents out of 2235 with $6.3 \%$. Also, with more than 20 influencer men, 22 scored higher with $9.3 \%$ compared with female, 13 with $5 \%$.

TABLE IX CONSUMER VICTIMIZED BY A LOUSY PRODUCT CATEGORIZED BY GENDER

\begin{tabular}{|l|c|c|c|}
\hline \multicolumn{4}{|c|}{ Consumer victimized by a lousy product categorized } \\
by gender & \multirow{2}{*}{ Total } \\
\hline & \multicolumn{2}{|c|}{ Gender } & \\
\hline & Female & Male & 94 \\
\hline No & 50 & 44 & 106 \\
\hline Yes & 50 & 56 & 35 \\
\hline May be & 15 & 20 & 235 \\
\hline Total & 115 & 120 & \\
\hline
\end{tabular}

As it is clear from the Table IX above that male, 56 out of 235 have been victimized by lousy product more than female. As above table that there were total (both male \& female) 235 respondent, out of them, 45.11\% (106) respondent were victimized by lousy product. So as far as concern with $45.11 \%$ (106 respondents), only 52.83\% (56 respondents) were male and rest $47.17 \%$ (50 respondents) were female. So, it is clear from the above table (10) that male have been victimized by lousy product more than the female.

TABLE X CONSUMER REACTION AFTER BUYING A LOUSY PRODUCT PROMOTED BY INFLUENCER BY GENDER

\begin{tabular}{|c|c|c|c|}
\hline \multicolumn{4}{|c|}{$\begin{array}{c}\text { Consumer reaction after buying a lousy product } \\
\text { promoted by influencer by gender }\end{array}$} \\
\hline & \multicolumn{2}{|c|}{ Gender } & \multirow{2}{*}{ Total } \\
\hline & Female & Male & \\
\hline Anger! & 8 & 6 & 14 \\
\hline Filing a lawsuit against them & 3 & 2 & 5 \\
\hline $\begin{array}{l}\text { Losing trust of the product/ } \\
\text { company/ influencer }\end{array}$ & 29 & 37 & 66 \\
\hline Never been in the situation & 46 & 39 & 85 \\
\hline Nothing & 4 & 6 & 10 \\
\hline Other & 6 & 6 & 12 \\
\hline Start to bad mouth them & 19 & 24 & 43 \\
\hline Total & 115 & 120 & 235 \\
\hline
\end{tabular}

From Table $\mathrm{X}$ when the participants were asked about their reaction to word a lousy product the majority voted never been in this experience both male and female. However, as the negative impact is higher in accumulation the majority of men lose faith of the product, service and influencer. second in higher reaction is starting to badmouth them with (19) female, and male with (24). The lowest rank reaction to both male and female is filing a lawsuit with (2) and (3) respectively. Actually, $3 \%$ of female population feel angry after buying a lousy product, and $2 \%$ of male population share the dame feeling. In an extreme reaction, $1 \%$ of female and $0.8 \%$ of male will file a lawsuit against them. Moreover, $2.5 \%$ of men and women will react in different way. However, $1.7 \%$ of female and $2.5 \%$ of male choose to be passive and do nothing.

TABLE XI OPINIONS ABOUT ENFORCING REGULATIONS IN SOCIAL MEDIA BY GENDER

\begin{tabular}{|l|c|c|c|}
\hline \multicolumn{3}{|c|}{$\begin{array}{c}\text { Opinions about enforcing regulations in social media } \\
\text { by gender }\end{array}$} \\
\cline { 1 - 3 } & \multicolumn{2}{|c|}{ Gender } & \multirow{2}{*}{ Total } \\
& Female & Male & \\
\hline Agree & 25 & 18 & 43 \\
\hline Disagree & 0 & 2 & 2 \\
\hline Strongly Disagree & 0 & 1 & 1 \\
\hline Strongly agree & 84 & 85 & 169 \\
\hline To some extent & 6 & 14 & 20 \\
\hline Total & 115 & 120 & 235 \\
\hline
\end{tabular}


As it is clear from the Table XI all female participants agree and strongly agree to use the force of law concerning unethical activities on social media. However, only 3 male participants disagree and strongly disagree to install legal regulations to unethical behavior on social media platforms. Little bit over $46 \%$ of female users agree or strongly agree to enforce regulations on social media. In the other hand, no one female population disagree to enforce regulations and laws regulating marketing in social networking platforms. Men, in the other hand agree and strongly agree by $42 \%$. Yet, there is $1 \%$ of male population disagree, and strongly disagree to enforce laws and regulations on social media.

As the Table XII illustrate male in gender are higher than female in both positive and negative impact of social media by (22). $8 \%$ of female feels that their life is impacted negatively with social media, which is lower than male who scored $9.3 \%$ of population. In the other hand $29 \%$ of female and $29.7 \%$ felt that social media affected their life positively. In addition, both female and male think that social media did not affect their lives positively nor negatively by $11.9 \%$.

Table XiI EfFects Of Social Media By Gender

\begin{tabular}{|l|c|c|c|}
\hline \multicolumn{3}{|c|}{ Effects of social media by gender } \\
\cline { 1 - 3 } & \multicolumn{2}{|c|}{ Gender } & \multirow{2}{*}{ Total } \\
\hline & Female & Male & \\
\hline Negatively & 19 & 22 & 41 \\
\hline Neither of & 28 & 28 & 56 \\
\hline Positively & 68 & 70 & 138 \\
\hline Total & 115 & 120 & 235 \\
\hline
\end{tabular}

Table XiII Usual Consumption Period In Social Media By Age

\begin{tabular}{|c|c|c|c|c|c|c|}
\hline \multicolumn{7}{|c|}{ Usual consumption period in social media by age } \\
\hline & \multicolumn{5}{|c|}{ Age } & \multirow{2}{*}{ Total } \\
\hline & 12 up to 19 & 20 up to 25 & 26 up to 30 & 31 up to 35 & Above 35 & \\
\hline 1 to 3 Hours & 6 & 4 & 22 & 21 & 22 & 75 \\
\hline 4 to 6 Hours & 8 & 15 & 25 & 20 & 13 & 81 \\
\hline Less than an 1 hours & 0 & 0 & 0 & 1 & 5 & 6 \\
\hline More than 6 hours & 15 & 22 & 19 & 13 & 4 & 73 \\
\hline Total & 29 & 41 & 66 & 55 & 44 & 235 \\
\hline
\end{tabular}

As the Table XIII shows the highest consumption of all period is 4-6 hours obtained by group age 26- 30 years old with 25 out of 235 respondents. In the other hand, no participants from group age 12-19, 20-25, and 26-30 use social media less than an hour. Based on age, $2 \%$ of population who is 12-19 years old are using social media platforms for 1-3 hours with 6 respondents out of $235.1 \%$ are 20-25 years old, 4 respondents. $9 \%$ are from 26-30, which are 22 respondents. $9 \%$ are 31-35with 21 respondents out of 235, and $9 \%$ are 35years and older with 22 respondents. The period of 4 to 6 hours is consumed by $3 \%$ from $12-19$ years, $6 \%$ by $20-25,10 \%$ by $26-30,8 \%$ by $31-$ 35 , and $5 \%$ by 35 years old and older. For the period, less than hour, $2 \%$ of 35 years and above, and $0.4 \%$ of group aged 31-35. There are no users between ages 12-30 years old who uses social media for less than an hour.

TABLE Xiv Number Of INFLUENCERS On PARTICIPANT's ACCOUNT By AgE

\begin{tabular}{|c|c|c|c|c|c|c|}
\hline \multicolumn{7}{|c|}{ Number of influencers on participant's account by age } \\
\hline & \multicolumn{5}{|c|}{ Age } & \multirow{2}{*}{ Total } \\
\hline & 12 up to 19 & 20 up to 25 & 26 up to 30 & 31 up to 35 & Above 35 & \\
\hline 11 to 20 & 4 & 7 & 12 & 7 & 7 & 37 \\
\hline 6 to 10 & 9 & 12 & 19 & 11 & 5 & 56 \\
\hline Less than 5 & 8 & 11 & 20 & 24 & 14 & 77 \\
\hline More than 2 & 3 & 9 & 11 & 9 & 3 & 35 \\
\hline None & 5 & 2 & 4 & 4 & 15 & 30 \\
\hline Total & 29 & 41 & 66 & 55 & 44 & 235 \\
\hline
\end{tabular}

As Table XIV illustrates the group aged 31-35 is the highest participants with 24 respondents who follows less than 5 influencers. And the lowest is 20 to 25 who are only 2 respondents out of 235 follows none of the influencers in social media. 
Table Xv Consumer Reaction After Buying A lousy Product Promoted By Influencer By Age

\begin{tabular}{|l|c|c|c|c|c|c|}
\hline \multicolumn{6}{|c|}{ Consumer reaction after buying a lousy product promoted by influencer by age } \\
\cline { 1 - 6 } & \multicolumn{5}{|c|}{ Age } & \multirow{2}{*}{ Total } \\
\hline & $\mathbf{1 2}$ up to 19 & $\mathbf{2 0}$ up to 25 & $\mathbf{2 6}$ up to 30 & 31 up to 35 & Above 35 & \\
\hline No & 11 & 15 & 30 & 23 & 15 & 94 \\
\hline Yes & 16 & 21 & 26 & 27 & 16 & 106 \\
\hline May be & 2 & 5 & 10 & 5 & 13 & 35 \\
\hline Total & 29 & 41 & 66 & 55 & 44 & 235 \\
\hline
\end{tabular}

Based on Table XV There is slight difference between group aged 26-35, of 26 respondents and 31-35, 27 respondents out of 235 when they were asked about being a victim of a lousy product. 27 participants from group age 31-35 answered yes. The majority of group age 26-31 with 30 respondents out of 235 did not fall for a lousy product.

Table Xvi Consumer Reaction After Buying A Lousy Product Promoted By Influencer By Age

\begin{tabular}{|l|c|c|c|c|c|c|}
\hline \multicolumn{7}{|c|}{ Age } \\
\hline
\end{tabular}

Table XVI illustrates, the feeling of anger was mostly coming from group age 20-25 with 6 respondents out of 235. Filing a lawsuit is equally between 12-19, and 31-35 with 2 respondents each out of 235 . Losing trust of the product, service and the influencer is a reaction that came from group age 26-30 with 17 respondents, and 31-35 with 17 respondents. Group age 26-30, with 29 respondents is the highest rank whom never been in this situation compared by
12-19, with 9 respondents out of 235 who was the lowest. Group age 26-30, with 4 respondents were more passive and prefer to take no reaction who also were opposite of group age 20-25 who have 0 participant that want to do nothing! the highest participants who acted in bad mouthing is from group range 31-35 years. As in education level the results came as follows.

TABLE XVII Number OF INFLUENCERS ON PARTICIPANT'S ACCOUNT By EDUCATION LEVEL

\begin{tabular}{|c|c|c|c|c|c|}
\hline \multicolumn{6}{|c|}{ Number of influencers on participant's account by education level } \\
\hline & \multicolumn{4}{|c|}{ Education } & \multirow{2}{*}{ Total } \\
\hline & Bachelor degree & High school & Higher Education & School drop out & \\
\hline 11 to 20 & 21 & 3 & 13 & 0 & 37 \\
\hline 6 to 10 & 30 & 10 & 16 & 0 & 56 \\
\hline Less than 5 & 39 & 10 & 27 & 1 & 77 \\
\hline More than 20 & 17 & 7 & 11 & 0 & 35 \\
\hline None & 15 & 8 & 7 & 0 & 30 \\
\hline Total & 122 & 38 & 74 & 1 & 235 \\
\hline
\end{tabular}

Table XVII bachelor degree holders have the highest follow of less than five influencers, 39 respondents and more than 20, 17 respondents out of 235 among all others. In addition, bachelor degree is highest on following influencers between
11-20 with 21 respondents. The lowest in education is the school dropout who only follows less than 5 influencers with 1 respondent out of 235 . 
Table XviII Consumer Reaction After Buying A Lousy Product Promoted By Influencer By Education Level

\begin{tabular}{|c|c|c|c|c|c|}
\hline \multicolumn{6}{|c|}{ Consumer reaction after buying a lousy product promoted by influencer by education level } \\
\hline & \multicolumn{4}{|c|}{ Education } & \multirow{2}{*}{ Total } \\
\hline & Bachelor degree & High school & Higher Education & School drop out & \\
\hline Anger! & 8 & 3 & 2 & 1 & 14 \\
\hline Filing a lawsuit against them & 1 & 2 & 2 & 0 & 5 \\
\hline Losing trust of the product/ company/ influencer & 31 & 8 & 27 & 0 & 66 \\
\hline Never been in the situation & 50 & 12 & 23 & 0 & 85 \\
\hline Nothing & 3 & 3 & 4 & 0 & 10 \\
\hline Other & 6 & 3 & 3 & 0 & 12 \\
\hline Start to bad mouth them & 23 & 7 & 13 & 0 & 43 \\
\hline Total & 122 & 38 & 74 & 1 & 235 \\
\hline
\end{tabular}

According to Table XVIII most bachelor degree holders did not fall for this experience with 50 respondents out of 235 equals $40 \%$ of all bachelor degree holders in the population, however when they fall for it their reaction is losing trust, by 31 respondents. $21 \%$ of High schoolers 8 respondents, and $63 \%$ of higher education holders, 27 respondents out of 235 also will lose trust. However, $100 \%$ school dropout, 1 respondent will react in anger.

Table Xix Opinions About Enforcing Regulations In Social Media By Education LeVel

\begin{tabular}{|c|c|c|c|c|c|}
\hline \multicolumn{6}{|c|}{ Opinions about enforcing regulations in social media by education level } \\
\hline & \multicolumn{4}{|c|}{ Education } & \multirow{2}{*}{ Total } \\
\hline & Bachelor degree & High school & Higher Education & School drop out & \\
\hline Agree & 20 & 7 & 15 & 1 & 43 \\
\hline Disagree & 1 & 0 & 1 & 0 & 2 \\
\hline Strongly Disagree & 1 & 0 & 0 & 0 & 1 \\
\hline Strongly agree & 92 & 26 & 51 & 0 & 169 \\
\hline To some extent & 8 & 5 & 7 & 0 & 20 \\
\hline Total & 122 & 38 & 74 & 1 & 235 \\
\hline
\end{tabular}

Table XIX shows that Bachelor degree holder, with 92 respondents out of 235 strongly agree to enforce regulations to minimize unethical behavior in social networking platforms. As appose only 2 bachelor degree holder disagree on that matter. Which means, $75 \%$ of bachelor degree holder think that there should be lows that governs marketing on social media.

Table Xx EfFects Of Social Media On Over All Life By Education LeVel

\begin{tabular}{|l|c|c|c|c|c|}
\hline \multicolumn{7}{|c|}{ Effects of social media on over all life by education level } & \multirow{2}{*}{ Total } \\
\hline & \multicolumn{5}{|c|}{ Education } \\
\hline & Bachelor degree & High school & Higher Education & School drop out & \\
\hline Negatively & 21 & 3 & 17 & 0 & 41 \\
\hline Neither of & 28 & 9 & 19 & 0 & 56 \\
\hline Positively & 73 & 26 & 38 & 1 & 138 \\
\hline Total & 122 & 38 & 74 & 1 & 235 \\
\hline
\end{tabular}

Finally, on Table XX, 73 of122 bachelor degree holders felt that social networks affect their life positively which is equal to $59 \%$ of all bachelor degree holder in the population. Only 21 respondents of 122 of the same degree felt that their life was impacted negatively, which is equal to $17 \%$. Most of high school experience is positive with 26 respondents out of 38 is positive experience this is equal to $68 \%$.
In the other hand 3 respondents out of 38 admit that their experience is negative which is equal to $7 \%$. Higher education responded positively with 39 out of 74 respondents which is equal to $52 \%$. 17 respondents out of 74 admitted that it affected them negatively which equal to $22 \%$. School dropout has $100 \%$ positive experience with only 1 respondent out of 1 . 


\section{Testing Hypothesis}

This study has raised many questions and formulated hypotheses related to the nature of the relationship and the impact between its variables, and reached several results that the researcher hopes to contribute to solving the problem of the study and answer the questions and test hypotheses.

1. $H_{0}$ : There is no relationship between impact of Social media marketing on consumer purchasing decisions.

2. $H_{l}$ : There is a relationship between impact of Social media marketing on consumer purchasing decisions.

TABLE XXI TESTING OF HyPOTHESIS

\begin{tabular}{|l|c|c|c|}
\hline \multicolumn{4}{|c|}{ Chi-Square Tests } \\
\hline & \multirow{2}{*}{ Value } & \multirow{2}{*}{ df } & Asymp. Sig. (2-sided) \\
\cline { 4 - 4 } & & & (significant level) \\
\hline Pearson Chi-Square & $19.386^{\mathrm{a}}$ & 8 & 0.013 \\
\hline Likelihood Ratio & 18.955 & 8 & 0.015 \\
\hline N of Valid Cases & 235 & & \\
\hline
\end{tabular}

The chi-square value is given as 19.386 at 0.01 significance level. The likelihood ratio value is 18.955 with eight degrees of freedom. The 0.001 significance level gives a 95\% confidence interval. The chi-square value is found to be 19.386. The tabulated value is at the same confidence interval, and significance level is found to be 15.50 which is a smaller value than the chi-square value. The $\mathrm{p}$-value obtained from the results is 0.000 which proves that it is not significant to lead to a conclusion. This therefore calls for the use of the chi-square value to test the hypothesis. Since the value of the chi-square is greater that the tabulated chisquare value, calculated value (19.386)> Table value (15.50) at the same significance level and confidence interval, then the results is that we reject the null hypothesis. It conclude that there is a relationship between impacts of Social media marketing on consumer purchasing decisions. Therefore, it is statistically proved that there is impact of social media on consumer purchasing behavior.

\section{FINDINGS AND RECOMMENDATIONS}

The results of the study showed that e-advertising on the social media platforms had a negative impact on consumer purchasing behavior in the Kingdom of Saudi Arabia. The study also showed that the chances increase of being a victim of stealth advertisement, unethical behavior, fake add, and exaggeration on promoting a product to those who spend 3 hours or more on social networking sites. As consumer spends this amount of time on social media, advertisements should be strong on content, accurate and truthful, to grasp the objectives of its being. Also, the study confirmed that male have been victimized by lousy product more than female. The results of the study also showed that the advertisements on the social communication platforms played a role in the negative impact on the behavior of consumer purchase in Saudi Arabia. And, among these platforms Snapchat which gain the supreme among other platforms in Saudi Arabia.

The majority of the participants are from the group aged 2530 who are using social media for 4-6 hours. The study proved statistically that $7 \%$ of female populations are not following any influencer, nor public figure account. As more people victimized by influencer promoting for a lousy product, others have admitted that they maybe were influenced by influencer's promoting a product. As we take it one step further, the vast majority of consumers wished to have laws and regulations for unethical behavior on social networks. The results have shown that as much as there are positive impact on consumer's over all life, yet some people admit that there is some negative impact as well.

\section{A. Recommendations}

The social networking sites emphasis on the importance of credibility in the content of advertising, in the sense of approval of what is advertised for the services provided on the ground. The consumers in age group (25-35) categories may be targeted market sectors because they are among the most age-groups in the Internet and social networking sites, and they can be used to promote the brand through viral marketing via word of mouth (e-WOM). Through the social media networking people victimized by influencers promoting a lousy product, others have admitted that they maybe were influenced negatively. It recommendsthat influencers to pay more attention to the quality of the product, service that they are promoting. Thus, promoting lousy products and services my harm both consumers and influencer reputation. This will lead losing the power of influence, as consumers lose trust on them. Many respondents take actions like start to badmouth the company and influencers, therefore, the study recommends both the company and influencer to be in charge whine there is a negative comment and complaints. Try to resolve the issue with great after sale eservice and with better handling the feed from angry followers. The study also recommends organizations, marketers influencers to pay more attention on the promotions and advertisements that they expose to their followers as it is impacts them both positively and negatively. The researcher recommends similar studies to study the effect of e-advertising on the purchasing behavior of other age groups not covered by the research. Furthermore, the researcher recommends further studies of the future; to identify the impact of electronic advertising on the behavior of purchasing goods and services.

\section{REFERENCES}

[1] Abo farah, Y. (2003). Electronic Marketing (1st ed., p. 66). Cairo: Dar Wael for printing, publishing and distribution.

[2] Aghaei, S. (2012). Evolution of the World Wide Web : From Web 1.0 to Web 4.0. International journal of Web \& Semantic Technology, 3(1), pp.1-10.

[3] Ama.org. (2017). Definition of Marketing. [online] Available at: https://www.ama.org/AboutAMA/Pages/Definition-of-Marketing. aspx [Accessed 17 Mar. 2017]. 
[4] Balas, J. L. (2006). The Social Ties That Bind. Online Treasures. Computers in Libraries, 26(2), 39-41.

[5] Banyai, M. (2012). Social media in travel, tourism, and hospitality: Theory, Practice and cases. Annals of Tourism Research, 39(3), 17461747. http://dx.doi.org/10.1016/j.annals.2012.05.008

[6] Bejou, D. (1997). Relationship marketing: Evolution, present state, and future. Psychology and Marketing, 14(8), pp.727-735.

[7] Bo Shnafa, A., \& Nafesah, N. (2012). Social networks as a tool for virtual marketing in the tourism field. In The Fifth International Forum: The Economy and its Implications for the International Economies. Melana.

[8] Bond, C., Ferraro, C., Luxton, S., \& Sands, S. (2010). Social media advertising: An investigation of consumer perceptions, attitudes, and preferences for engagement. Melbourne: Monash University ANZMAC.

[9] Botwinick, J. (2013). Aging and behavior: A comprehensive integration of research findings. Springer.

[10] Carr, N. G. (1999). Marketing-The economics of customer satisfaction.

[11] Chaoying, T., Jian, S., \&Ille, F. R. (2011). Information handling styles, advertising and brand attitude: A Chinese brand case study. International Journal of China Marketing, 1(2), 45.

[12] Danesi, M. (2014). Dictionary of media and communications. Routledge, Chicago.

[13] Eaton, J. (2006). E-Word-of-mouth marketing. University of Arizona.

[14] Edrees, T., \& Almorsy, J. (2005). Contemporary marketing (1st ed., p. 435). Alexandria: AldarAljameyah.

[15] Fayyaz, N., \& Lodhi, M. S. (2015). Deceptive Advertising Practices and Customer Loyalty A Case of Mobile Phones in Karachi, Pakistan. International Journal of Scientific and Research Publications, 469

[16] Fisher, R. J., \& Dube, L. (2003). Gender Differences In Responses to Emotional Advertising: The Effect of the Presence of Others. Advances in Consumer Research, 30(1).

[17] Global Web Index. (2016). Saudi arabia GWI Market report Q4 2016 (p. 12). London.

[18] Goodwin, N., Nelson, J. A., Ackerman, F., \& Weisskopf, T. (2008). Consumption and the consumer society. Retrieved December, 15, 2008.

[19] Heath, R., \& Feldwick, P. (2008). Fifty years using the wrong model of advertising. International journal of market research, 50(1), 29.

[20] Hunt, S. (1976). The Nature and Scope of Marketing. Journal of Marketing, 40(3), p.17.

[21] Jaworski, B. (1988). Toward a Theory of Marketing Control: Environmental Context, Control Types, and Consequences. Journal of Marketing, 52(3), 23.

[22] John, R. R., \& Percy, L. (1997). Advertising Communications and Promotion Management.

[23] Keller, K. L. (1998). Strategic brand management (Vol. 256). Upper Saddle River, NJ: Prentice Hall.

[24] Kim, J. (2012). An empirical study on consumer first purchase intention in online shopping: integrating initial trust and TAM. Electronic Commerce Research, 12(2), 125-150. http://dx.doi.org/10.1007/s10660-012-9089-5

[25] Kotler, P., Keller, K., Manceau, D., \&Hemonnet-Goujot, A. (2014). Marketing management (14th ed.). Montreuil: Pearson France.

[26] Lendrevie, J., \&Lévy, J. (2012). Mercator (10th ed.). Paris: Dunod.

[27] MacKenzie, S. B., Lutz, R. J., \& Belch, G. E. (1986). The role of attitude toward the ad as a mediator of advertising effectiveness: A test of competing explanations. Journal of marketing research, 130143.

[28] Mangold, W. G., \& Faulds, D. J. (2009). Social media: The new hybrid element of the promotion mix. Business horizons, 52(4), 357365.

[29] Mata, R., \& Nunes, L. (2010). When less is enough: Cognitive aging, information search, and decision quality in consumer choice. Psychology and Aging, 25(2), 289-298. http://dx.doi.org/10.1037/ a0017927

[30] Miller, C. R., \& Shepherd, D. (2004). Blogging as social action: A genre analysis of the weblog. Into the blogosphere: Rhetoric, community, and culture of weblogs, 18(1), 1-24.

[31] Mitchell, A. A. (1986). The effect of verbal and visual components of advertisements on brand attitudes and attitude toward the advertisement. Journal of consumer research, 13(1), 12-24.
[32] Mitra, A., Raymond, M. and Hopkins, C. (2008). Can consumers recognize misleading advertising content in a media rich online environment? Psychology and Marketing, 25(7), pp.655-674.

[33] Park, C. H., \& Kim, Y. G. (2003). Identifying key factors affecting consumer purchase behavior in an online shopping context. International Journal of Retail \& Distribution Management, 31(1), 16-29.

[34] Petty, R. E., Cacioppo, J. T., \& Schumann, D. (1983). Central and peripheral routes to advertising effectiveness: The moderating role of involvement. Journal of consumer research, 10(2), 135-146.

[35] Phelps, J., \& Hoy, M. (1996). The Aad-Ab-PI relationship in children: The impact of brand familiarity and measurement timing. Psychology And Marketing, 13(1), 77-105. http://dx.doi.org/10.1002/ (sici)1520-6793(199601)13:1

[36] POST strategy. (2014). Forrester. Retrieved 9 April 2017, from http:// forrester.typepad.com/groundswell/2007/12/the-post-method.html.

[37] Prendergast, G., Ko, D., \& Siu Yin, V. Y. (2010). Online word of mouth and consumer purchase intentions. International Journal of Advertising, 29(5), 687-708.

[38] Rathus, S. (2013). Psychology (1st ed., p. 470). Australia: Wadsworth Cengage Learning.

[39] Roblyer, M., McDaniel, M., Webb, M., Herman, J., \& Witty, J. (2010). Findings on Facebook in higher education: A comparison of college faculty and student uses and perceptions of social networking sites. The Internet and Higher Education, 13(3), 134-140. http://dx.doi.org/10.1016/j.iheduc.2010.03.002

[40] Safko, L., \& Brake, D. (2012). The Social Media Bible: Tactics, Tools \& Strategies for Business Success (1st ed.). Hoboken, N.J.: Wiley.

[41] Sahney, S. (2011). Module-5 Consumer Behavior. Vinod Gupta School of Management Indian Institute of Technology Kharagpur, India.

[42] Saleh, S. (2011). In The New Media and Community Issues: Challenges and Opportunities. King Abdulaziz University, Jeddah.

[43] Schiffman, L., \& Kanuk, L. (2009). Consumer behavior (1st ed.). Harlow: Pearson Education International.

[44] Schiffman, L., \& Wisenblit, J. (2015). Consumer behavior (1st ed., p. 269). Boston: Pearson.

[45] Shultz, T. (2013). Evaluating Moral Issues in Motivation Theories: Lessons from Marketing and Advertising Practices. Employee Responsibilities and Rights Journal, 26(1), 1-20. http://dx.doi.org/ 10.1007/s10672-013-9230-1

[46] Sloan, L., Morgan, J., Housley, W., Williams, M., Edwards, A., Burnap, P., \& Rana, O. (2013). Knowing the Tweeters: Deriving Sociologically Relevant Demographics from Twitter. Sociological Research Online, 18(3). http://dx.doi.org/10.5153/sro.3001.

[47] Statista, (2017). Digital Advertising - Saudi Arabia | Statista Market Forecast. Statista. Retrieved 16 April 2017, from https://www.statista. com/outlook/216/110/digital-advertising/saudi-arabia\#

[48] Statista. (2017). Instagram: active users 2016 | Statista. Statista. Retrieved 5 April 2017, from https://www.statista.com/statistics/ 253577/number-of-monthly-active-instagram-users/

[49] Statista. (2017). Twitter: number of active users 2010-2016 | Statista. Statista. Retrieved 13 April 2017, from https://www.statista.com/ statistics/282087/number-of-monthlyactive-twitter-users/

[50] Taylor, H. (2016). If social networks were countries, which would they be?. World Economic Forum. Retrieved 12 April 2017, from https://www.weforum.org/agenda/2016/04/facebook-is-bigger-thanthe-worlds-largest-country/

[51] Taylor, W. (1965). Is Marketing a Science? Revisited. Journal of Marketing, 29(3), 49.

[52] Thomases, H. (2009). Twitter marketing: An hour a day. John Wiley \& Sons. p. 60

[53] Top Sites in Saudi Arabia - Alexa. (2017). Alexa.com. Retrieved 12 April 2017, from http://www.alexa.com/topsites/countries/SA

[54] Tuten, T.L., \& Solomon, M.R. (2014). Social media marketing. Sage.

[55] Van Norel, N. D., Kommers, P. A., Van Hoof, J. J., \& Verhoeven, J. W. (2014). Damaged corporate reputation: Can celebrity Tweets repair it? Computers in human behavior, 36, 308-315.

[56] Wagner, K. (2017). Snapchat lowered its ad rates for Discover. CNBC. Retrieved 14 April 2017, from http://www.cnbc.com/2015/ 05/08/snapchat-lowered-its-ad-rates-for-discover.html

[57] Zikmund, W. G., Babin, B. J., Carr, J. C., \& Griffin, M. (2013). Business research methods. Cengage Learning. 